\title{
ATXN1 wt Allele
}

National Cancer Institute

\section{Source}

National Cancer Institute. ATXN1 wt Allele. NCI Thesaurus. Code C129916.

Human ATXN1 wild-type allele is located in the vicinity of $6 \mathrm{p} 22.3$ and is approximately $462 \mathrm{~kb}$ in length. This allele, which encodes ataxin-1 protein, plays a role in Notch signaling, chromatin binding and RNA metabolism. CGA repeat expansion within the coding region of the gene is associated with spinocerebellar ataxia 1. 